\title{
The gender dimensions of the globalization of production
}

\author{
Working Paper No. 17 \\ Stephanie Barrientos \\ Naila Kabeer \\ Naomi Hossain
}

Policy Integration Department

World Commission on the Social Dimension of Globalization

International Labour Office

Geneva

May 2004 
Copyright $(C$ International Labour Organization 2004

Publications of the International Labour Office enjoy copyright under Protocol 2 of the Universal Copyright Convention. Nevertheless, short excerpts from them may be reproduced without authorization, on condition that the source is indicated. For rights of reproduction or translation, application should be made to the Publications Bureau (Rights and Permissions), International Labour Office, CH-1211 Geneva 22, Switzerland. The International Labour Office welcomes such applications.

Libraries, institutions and other users registered in the United Kingdom with the Copyright Licensing Agency, 90 Tottenham Court Road, London W1T 4LP [Fax: (+44) (0)20 7631 5500; email: cla@cla.co.uk], in the United States with the Copyright Clearance Center, 222 Rosewood Drive, Danvers, MA 01923 [Fax: (+1) (978) 750 4470; email: info@copyright.com] or in other countries with associated Reproduction Rights Organizations, may make photocopies in accordance with the licences issued to them for this purpose.

ISBN 92-2-116007-6 (printed version)

ISBN 92-2-116008-4 (web version)

First published 2004

Cover:

The designations employed in ILO publications, which are in conformity with United Nations practice, and the presentation of material therein do not imply the expression of any opinion whatsoever on the part of the International Labour Office concerning the legal status of any country, area or territory or of its authorities, or concerning the delimitation of its frontiers.

The responsibility for opinions expressed in signed articles, studies and other contributions rests solely with their authors, and publication does not constitute an endorsement by the International Labour Office of the opinions expressed in them.

Reference to names of firms and commercial products and processes does not imply their endorsement by the International Labour Office, and any failure to mention a particular firm, commercial product or process is not a sign of disapproval.

ILO publications can be obtained through major booksellers or ILO local offices in many countries, or direct from ILO Publications, International Labour Office, CH-1211 Geneva 22, Switzerland. Catalogues or lists of new publications are available free of charge from the above address, or by email: pubvente@,ilo.org

Visit our website: $\underline{\text { Www.ilo.org/publns }}$

Printed by the International Labour Office, Geneva, Switzerland 


\section{The gender dimensions of the globalization of production}

Contents

Foreword iii

Preface. $\mathrm{V}$

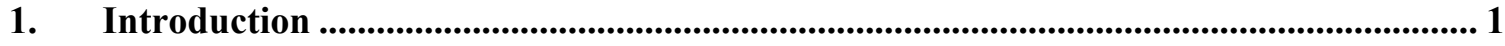

2. The changing nature of global production and the participation of female labour ...... 2

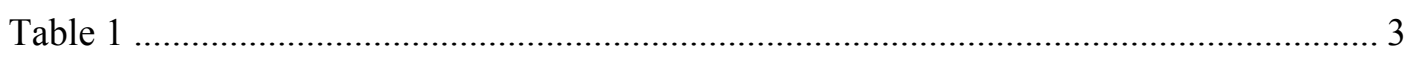

3. Gender and employment in manufacturing .......................................................... 4

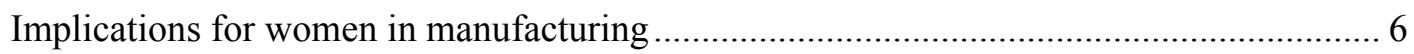

4. Gender and employment in high-value agriculture ...................................................... 8

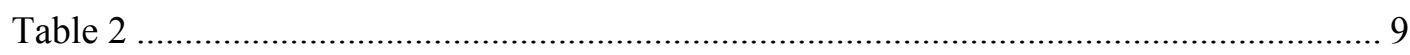

Implications for women in high-value agricultural exports (HVAEs) .............................. 10

5. Enhancing female employment in global production: Policy implications .................... 12

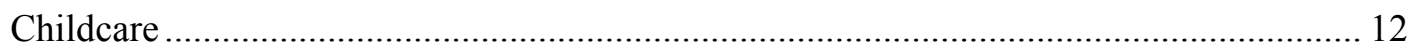

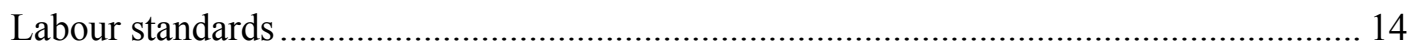

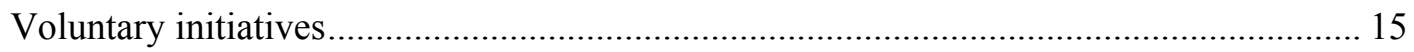

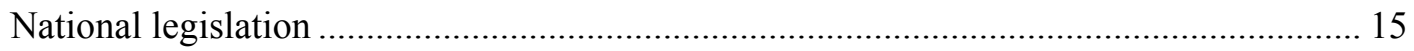

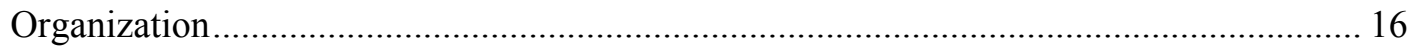

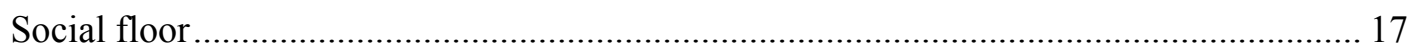

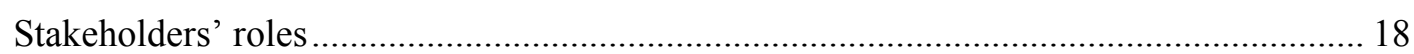

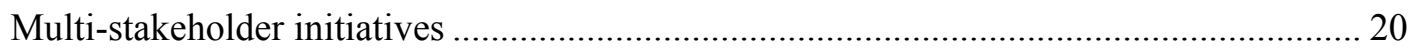

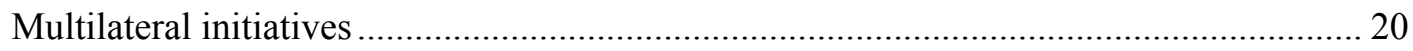

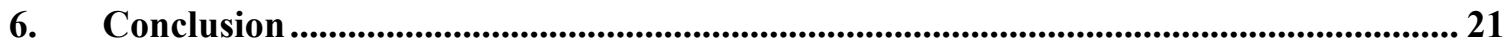

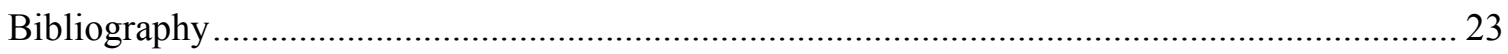





\title{
Foreword
}

In February 2002, the ILO established an independent World Commission on the Social Dimension of Globalization, co-chaired by President Tarja Halonen of Finland and President Benjamin Mkapa of Tanzania and comprising 26 eminent commissioners from a wide range of walks of life and different parts of the world, each serving in their individual capacity. Its broad goals were: to identify policies for globalization that reduce poverty, foster growth and development in open economies, and widen opportunities for decent work; to explore ways to make globalization inclusive, so that the process can be seen to be fair for all, both between and within countries; to promote a more focused international dialogue on the social dimension of globalization; to build consensus among key actors and stakeholders on appropriate policy responses; and to assist the international community forge greater policy coherence in order to advance both economic and social goals in the global economy.

The report of the World Commission, A fair globalization: Creating opportunities for all, was released on 24 February 2004. It is available on the Commission's website www.ilo.org/public/english/wcsdg/index.htm.

A secretariat was established by the ILO to support the Commission. Among other tasks, it compiled information and commissioned papers on different aspects of the social dimension of globalization. The aim was to provide the Commission with documentation and data on a wide range of options and opinions concerning subjects within its mandate, without committing the Commission or individual Commissioners to any particular position on the issues or policies concerned.

Material from this background work is being made available as working papers, as national and regional reports on meetings and dialogues, and in other forms. Responsibility for the content of these papers and publications rests fully with their authors and their publication does not constitute an endorsement by the World Commission or the ILO of the opinions expressed in them.

\author{
Gerry Rodgers \\ Director \\ Policy Integration Department
}





\section{Preface}

The Technical Secretariat to support the World Commission on the Social Dimension of Globalization first prepared a synthesis of ILO activities on the Social Dimension of Globalization (published as Working Paper No. 1 in this series). Documentation on the work and outcomes of other major commissions, an ideas bank, a database and knowledge networks of experts and social actors were subsequently developed. These networks have dealt with several topics, including: inclusion at the national level for the benefits of globalization to reach more people; local markets and policies; cross-border networks of production to promote decent work, growth and development; international migration as part of the Global Policy Agenda; international governance (including trade and finance); the relationship between culture and globalization; and values and goals in globalization. Gender and employment aspects were addressed throughout this work. The Reports on the Secretariat's Knowledge Network Meetings are available on the Commission's web site or in a special publication from the ILO (ISBN 92-2-115711-1).

During the course of these activities, a number of substantive background papers were prepared, which are now made available for wider circulation in the Policy Integration Department's Working Paper series (Nos. 16 to 38), as well as on the Commission's website.

This paper was written by Stephanie Barrientos, Naila Kabeer and Naomi Hossain of the Institute for Development Studies at the University of Sussex. An earlier version was produced for the Knowledge Network on Cross Border Networks of Production Systems organized by Susan Hayter.

The authors observe that the globalization of production has opened up opportunities for women to enter new areas of paid employment, earn an income, gain independence and participate more actively in social life. But it has also created new challenges, as much of this employment is informal, with poor working conditions and a lack of labour rights, and has to be carried out in addition to household and family responsibilities. The globalization of production is increasingly based on integrated global value chains, in which there are direct linkages between production, distribution and retailing. A "continuum" is emerging between formal and informal work in global production. Gender inequality arises because men are more likely to be concentrated towards the formal end of the continuum and women towards the informal end (with some exceptions). But it is also important to note, that employment in global production is not inherently negative for women. For many women, working in exports is better than the alternatives of working (or being unemployed) in the domestic economy.

The authors argue that policies need to address both the labour rights of productive workers (especially those in informal employment) and the related reproductive rights of women workers in relation to childcare and social issues. Globalization has changed the role that the various stakeholders can play in supporting more gender-sensitive policies involving government, the private sector, trade unions and other civil society organizations. The key is how to enhance a partnership approach between stakeholders to develop more "joined up" policy initiatives that are gender sensitive and take into account the changing roles of women in the world of work and at home.

\section{Rolph van der Hoeven \\ Manager, Technical Secretariat \\ World Commission on the Social Dimension of Globalization}

May 2004 



\section{The gender dimensions of the globalization of production}

\section{Introduction}

The gender dimensions of the globalization of production have undergone a rapid process of transformation over the past two decades. This is reflected at a number of levels in terms of the changing relations of global production and employment, the changing patterns of global consumption and the changing forms of reproduction. We now live in a fast-moving global world, linking large numbers of workers and consumers across developed and developing countries, which has important implications for the ways in which women and men organize their work and lives. This transformation has affected women and men in contradictory ways. It has opened up opportunities for women to enter new areas of paid employment, earn an income, gain independence and participate more actively in social life. But it has also created new challenges, as much of this employment is informal, with poor working conditions and a lack of labour rights, and has to be carried out in addition to household and family responsibilities.

A traditional model of the gender division of labour within society was based on a clear separation between productive activity, with men primarily concentrated in formal paid work, and reproductive activity, with women focused on household and childcare responsibilities, possibly combined with informal work. The globalization of production is increasingly based on integrated global value chains, in which there are direct linkages between production, distribution and retailing. These involve a high degree of supply flexibility across countries, facilitated by the mobility of capital and finance, and characterized by just-in-time global delivery systems. Global production has drawn both women and men into new forms of flexible employment, and women's participation in the labour force is rising in many countries.

In addition to being flexible (part-time, temporary, casual), much of the employment in global production is also informal, without an employment contract or the associated rights that flexible workers with a contract should receive. This allows producers to further shift the costs and risks of production (from adverse conditions or market fluctuations) onto workers. Traditionally, the division between formal and informal forms of working has been denoted by distinct formal and informal sectors. This rigid classification is untenable in a global economy in which the boundary between formal and informal is blurred, and informal workers are increasingly employed within "formal" sectors. This process has been accelerated in a climate of deregulation, with increasing numbers of both men and women now employed in "informal" types of employment, as the share of secure, permanent, full-time jobs declines throughout the world (ILO, 2002; Lund and Srinivas, 2000; Standing, 1999b). Today, informal working arrangements are becoming the norm in many export sectors dominated by global value chains. Gender inequality arises because women are more likely to be concentrated in informal work, with few labour rights and little social protection.

A "continuum" is emerging between formal and informal work in global production. Towards the informal end of the continuum, workers lack security of employment, have few employment rights, receive inadequate employment benefits or social protection, lack trade union organization and bear a high level of risk and vulnerability within employment (Barrientos and Barrientos, 2002). This continuum is often replicated in global value chains, where more formal employment is found at certain prominent nodes within the chain, but as the supply end becomes more fragmented, employment becomes more informal (for example, through the use of contract labour and homeworkers). Some workers are at one or other of the ends of the continuum, but most are somewhere in 
between. Gender inequality arises because men are more likely to be concentrated towards the formal end of the continuum and women towards the informal end (with some exceptions).

It is also important to note, however, the view of a number of observers that employment in global production is not inherently negative for women. The reality is that, for many women, working in exports is better than the alternatives of working (or being unemployed) in the domestic economy. Further, the advantages and disadvantages need to be weighed up not only in relation to paid productive work, but also the manner in which this is balanced with and affects women's reproductive role. There may be advantages to being able to organize production in ways that fit in with women's other tasks (see Elson, 1996; Wilson, 1991). But the protection of wages and wage levels, and indeed the extension of other benefits for casual, home-based and workshop employees and other forms of highly flexible labour, present a significant challenge for traditional forms of labour organization. A nuanced analysis that takes all of these factors into account is therefore needed of the advantages and disadvantages for women of paid employment in export production. In this way, it will be possible to examine the obstacles preventing women from reaping the advantages of work in global production in comparison with men, the enhancement of gender equity in employment and women's access to the rights and benefits associated with employment.

This paper seeks to address these issues. It starts by reviewing existing information on changing global production systems and gender employment trends, focusing on export agriculture and manufacture. The opportunities and constraints that changing global production has generated for women workers are then analysed. Women continue to bear primary responsibility for reproduction, but combine this with work that is often informal and without access to formal labour rights and protection. Yet increasingly this informal work is linked to global production. It is argued that, to be effective in improving gender equity in employment, policies need to address both the labour rights of productive workers (especially those in informal employment) and the related reproductive rights of women workers in relation to childcare and social issues. Globalization has changed the role that the various stakeholders can play in supporting more gender-sensitive policies involving government, the private sector, trade unions and other civil society organizations. The key is how to enhance a partnership approach between stakeholders to develop more "joined up" policy initiatives that are gender sensitive and take into account the changing roles of women in the world of work and at home.

\section{The changing nature of global production and the participation of female labour}

Globalization has stimulated significant changes in most developing and developed countries over the past two decades. The liberalization of trade and financial markets, combined with rapid advances in information technology and transportation systems, have facilitated the development of new industries and agro-industries. Patterns of production have changed, shifting from agriculture towards industry and services. Export-oriented growth and the expansion of trade have deepened the linkages between production in developing countries and world markets. Some notable areas in which this has taken place include the production of high-value consumer goods, such as garments, shoes, electronics, exotic foods, flowers and wines. These goods are sold by large brand name companies or retailers which often have little or no involvement in their production. They are sourced from all over the world through a network of global suppliers, often based in developing countries, linked into global value chains.

These changes in production patterns have been associated with changing trends in employment. They have also been associated with changes in the gender distribution of 
employment (see Kabeer, 2003). The first and most striking change has been the rise in the percentage of women in the labour force in almost every region of the world except subSaharan Africa and East Asia, where it was already high. Secondly, in almost every region, women's employment has increased faster than that of men. As a result, women's share of paid work has increased since 1980 (ILO, 1996). With a stagnating, or in some cases decreasing male labour force, gender differences in labour force participation have shrunk in many regions. These changes are summarized in Table 1. An important factor in the rise in female labour force participation has been the changing nature of the global economy as countries shift from "closed" to "open" trade regimes and from regulated to deregulated labour markets. The search for "flexible" forms of labour, particularly in labour-intensive and lower value added areas of production, have benefited women to a greater extent than men.

\section{Table 1}

Trends in adult activity rates between 1975 and 1995, by percentage of countries with each type of change, total and by gender

\begin{tabular}{|c|c|c|c|}
\hline Gender & Type of change & $\begin{array}{r}\text { Developing } \\
\text { countries }\end{array}$ & $\begin{array}{r}\text { Developed } \\
\text { countries }\end{array}$ \\
\hline \multirow{4}{*}{ Women } & Increased & 74 & 70 \\
\hline & Decreased & 17 & 15 \\
\hline & No change & 9 & 15 \\
\hline & Total & 100 & 100 \\
\hline \multirow{4}{*}{ Men } & Increased & 26 & 5 \\
\hline & Decreased & 66 & 95 \\
\hline & No change & 9 & 0 \\
\hline & Total & 100 & 100 \\
\hline \multirow{5}{*}{ Total } & Increased & 52 & 35 \\
\hline & Decreased & 40 & 45 \\
\hline & Compensated $\left({ }^{*}\right)$ & 3 & 20 \\
\hline & No change & 6 & 0 \\
\hline & Total & 100 & 100 \\
\hline
\end{tabular}

Source: able from Standing (1999a: 587 ).

$\left({ }^{*}\right) \quad$ Cases in which the activity rates of men and women changed in the opposite direction, involving a fall in male and a rise in female activity rates, so that they approximately offset each other.

The third major change relates to the distribution in the female labour force between different sectors, the trends of which partly reflect those of the global distribution of labour. The female labour force in agriculture has declined or remained static in most regions. However, it still accounted for around 62 per cent of total female employment in 1990 and remains the most important source of employment for women in South Asia and sub-Saharan Africa. The share of total female employment in manufacturing has increased in many developing countries, particularly in East and South-East Asia. In those areas of Africa, Western Asia and the OECD where it has fallen, the decline has largely been compensated by an increase in services (Mehra and Gammage, 1999). Indeed, the overall increase in women's activity rates globally has been mainly absorbed by clerical, retail and service employment.

These increases in female labour force participation also reflect a rise in the participation of women in the "traded" sectors of the global economy. In some parts of the world, this has taken the form of higher participation in manufacturing employment as economies 
have shifted from capital-intensive import-substituting industrialization to labour-intensive export-oriented industrialization: "it is now considered a stylized fact that industrialization in the context of globalization is as much female-led as it is export-led" (United Nations, 1999: 9). Elsewhere, it has risen in response to growing opportunities in high-value agricultural exports and export-oriented services, such as tourism, information processing and financial services. This paper focuses primarily on manufacturing and high-value agricultural exports.

\section{Gender and employment in manufacturing}

Women now represent more than one-third of the manufacturing labour force in developing countries and nearly a half in some Asian countries. The greatest increases over the past 20 years have occurred in countries which have adopted export-oriented strategies. The 1980s and 1990s saw the intensification of processes which had started in the 1960s, in which multinational corporations (MNCs) based in the already industrialized North sought higher profit margins by outsourcing production to producers in developing countries, mainly (although not solely) in order to take advantage of the lower cost and less unionized labour in those countries. Whereas this process of sourcing production or assembly in countries with abundant cheap labour originally took American and European companies to East and later South-East Asia, as from the 1980s there has been a growth in the manufacturing industry in Latin America and the Caribbean, South Asia and parts of sub-Saharan Africa. These most recent industrializers are also increasingly producing for East-Asian buyers, particularly in Japan and the Republic of Korea.

The globalization of markets for manufactured goods has intensified competitive pressures to produce at lower cost with shorter lead times and increasingly differentiated product lines. These pressures have led to an increasing emphasis on "flexibility" in the manufacturing industry, to enable shorter production runs, facilitate rapid shifts between different products and product specifications for different markets, and to do so at ever lower costs. Some of this flexibility has been achieved through technological changes, which have allowed companies to adopt just-in-time strategies, minimizing inventories and responding rapidly to changes in demand. Some of it has been achieved through more decentralized forms of management which promote creative responsiveness and innovation throughout the production process. Most importantly, however, it has been achieved through forms of employment that are temporary, part-time, casual or contract-based.

This process has been described as the double feminization of labour markets (Standing, 1999a). One aspect of this feminization refers to the growing numbers of women within the global labour force, mainly concentrated in repetitive assembly line work in export-oriented "light" industry subsectors, such as garments, textiles, shoes and electronics. Whereas the typical industrial worker in the Fordist era after the Second World War was a European or American male working in capital-intensive "heavy industry", who could expect lifelong job security in a reasonably tight labour market, the right to join a union, some statutory or firm-based benefits and protections and a "family wage" which assumed full-time housework for women, the typical manufacturing worker is now more likely to be a young single Asian woman employed in labour-intensive, low value added stages of production, paid wages too low to cover a household's basic costs and enjoying very little social protection (see Standing 1999a; Mehra and Gammage, 1999). She is also increasingly likely to work, not in a factory in the formal economy, but in small workshops or home-based work at the more informal end of a formal/informal continuum (see Chen et al., 1999; contributions to Chhachhi and Pittin, 1996; and Ghosh, 2001).

Manufacturing employment has also been "feminized" in another sense, which is that employment conditions for all workers (including men) have become less secure and 
protected, more "casualized" and temporary, and less well paid, or in other words they have become more like the jobs that women have customarily accepted. This appears to be a trend in employment conditions across the world, and not only in export-oriented newly industrializing countries (Standing, 1999a). It has occurred in a context in which older trade union organizations have been weakened and new ones prevented from emerging.

However, these processes of feminization have not occurred evenly across the world and may even have been reversed in some areas. While the available cross-country statistics on women's employment in manufacturing indicate that the overall trend since the 1970s has been one of expansion, evidence is emerging that the latter half of the 1990s saw something of a "de-feminization". In the more "mature" industrializing economies of East and South-East Asia and in the maquiladoras in Mexico, women's share of manufacturing employment appears to have started to decline even earlier.

The "de-feminization" of the manufacturing industry started in Japan, the first of the Asian industrializers, where a shift in female employment from large-scale manufacturing industry into services occurred from the 1970s: over 36 per cent of women workers were in manufacturing in 1960, a proportion which declined to 26 per cent by 1990 (Maki, 1993; see also Park, 1995, for similar patterns in the Republic of Korea). Industrial restructuring in Hong Kong (China) from the late 1980s meant an overall decline in manufacturing employment, but the brunt of job losses in industry were borne by women: the number of women workers in manufacturing fell by 61 per cent between 1987 and 1995, as compared to the (still substantial) 52 per cent decline in the number of male employees. Mexico too has seen a systematic decline in the share of women's employment in the maquiladoras, from about 85 per cent of all employment in the earliest years, to 78 in 1975 and 64 per cent in 1988, (Tiano, 1994: 24). By 1999, women accounted for around 41 per cent. During this period, employment in maquiladoras across Mexico was increasing from around 100,000 in the early 1980 s to 750,000 at the end of the 1990s (Fussell, 2000).

What explains these trends and what happens to the women workers who lose or fail to find jobs is obviously of considerable policy interest. One explanation of the decline in women's share of manufacturing employment in the "mature" "new industrializers" relates to the adoption of "flexible" in place of "mass" production systems. Although developed in Japan, these systems have been adopted by a number of developed as well as developing countries. They are based on generalized rather specialized equipment, incorporating micro-electronic technologies and requiring multi-skilled workers capable of performing a variety of different tasks. Competitive advantage has consequently shifted from labourintensive to capital-intensive technology and from the costs of labour to its quality and skills.

Larger enterprises concentrate on the cultivation of a privileged "core" labour force of multi-skilled workers, but respond to changes in market conditions through subcontracting arrangements with small units, many of which employ a peripheral labour force, who work long hours with minimal training, low pay, poor working conditions and very little protection, and who may be periodically laid off. It is primarily men who are perceived as having the necessary education and technical skills to manage the new generalized technologies and who make up the core work force, with women tending to predominate in smaller subcontracting firms. Subcontracting has also allowed the earlier industrializers, such as Japan and the Republic of Korea, faced with tightening labour markets and increasing real wages, to engage in off-shore arrangements with firms in neighbouring areas of Asia, where wages are lower. The decline in female employment in manufacturing in such economies is linked to these processes of restructuring.

Along with these dual processes of "recapitalization" and "informalization" (Mehra and Gammage, 1999), there are other less well-documented explanations for the observed defeminization processes of manufacturing employment. Ghosh (2001) has argued, for instance, that in East and South-East Asia, there may have been a rise in the relative costs 
of hiring women and that a higher female presence in the industrial workforce may have led to pressure for more woman-friendly labour legislation. In cases where the earlier profile of young single women with few domestic responsibilities has given way to a more mixed workforce of older and married women (see, for example, Tiano, 1994; Nam, 1991; Maki, 1993; Park, 1995; Kabeer and Mahmud, 2004; Kabeer and Van Anh, 2002; Brinton et al., 1995), there is likely to be greater pressure for maternity and related benefits.

Responses to this pressure have varied. Certainly, both Japan (Maki, 1993) and the Republic of Korea (Palley, 1990) adopted gender equity legislation in the late 1980s. It is certainly possible that women became less attractive as industrial employees in the Republic of Korea as they became increasingly militant (Deyo, 1989); certainly, union activity is considered to have helped to reduce wage differentials there (Wilkinson, 1994). In Singapore, where rapid industrialization and the increasing entry of younger women into secondary and tertiary education has led to a tighter labour force, the Government has adopted a number of measures to attract and stabilize women's participation in the labour force (Siok-Hwa, 1977). In Bombay, however, factory managers in the 1980s explained that the advantages of employing women disappeared once they became unionized (Hensman, 1996).

One other factor that explains the declining share of female employment in manufacturing may be related to the other aspect of "feminization" suggested by Standing. In other words, in contexts of high or growing levels of male unemployment, men may be willing to compete on comparable terms with women. Kabeer (2000) notes that the clothing industry in London, initially female-intensive, came to rely on the labour of male (mainly Bangladeshi) immigrants, who had few opportunities in a racially-segmented labour market and have proved willing to work under sweatshop conditions in the informal economy. Kopinak (1995) suggests that young working class men in the northern Mexican border regions were being socialized into becoming docile labour, as the absence of unions and workforce discipline came to be accepted by the working class: it then became possible for the industry to hire young, inexperienced and docile men.

In view of these varied factors underlying the declining share of female manufacturing employment, the fate of the women workers who have been laid off or failed to find manufacturing work has also varied. In a few cases, they have been forced to retreat into domesticity (see Chiu and Lee, 1997, concerning Hong Kong (China), and Jacka, 1990, on China). In other parts of East and South-East Asia, women have moved in large numbers into the tertiary sector: clerical, retail and service employment. In the Republic of Korea and Taiwan (China), this has been facilitated by the decline in marriage-related obstacles to women's employment in "white collar" jobs, which had operated in the early phase of industrialization. Elsewhere, however, the shift has been into part-time and less secure forms of employment, often in informal manufacturing units (Ghosh, 2000; Fussell, 2000). In other words, the form and location of women's work may have altered in the course of the recent phase of globalization, but they remain involved insofar as possible with the paid economy.

\section{Implications for women in manufacturing}

Many studies of women workers in manufacturing report improvements in women's well-being, usually through an increased sense of economic agency and self-worth and the capacity to renegotiate relations with parents and husbands. Such findings come from a variety of different contexts: Bangladesh (Kabeer, 2000); China (Davin, 2001); Mexico (Wilson, 1991) and Latin America more generally (see Chant, 2002); Taiwan (China) (Diamond, 1979); Philippines (Chant and Mcllwaine, 1995). Yet it is also true, and in particular for older and married women, that factory employment frequently offers the possibility of household survival under conditions of economic decline or, as in Mexico in the 1980s, of keeping up with galloping inflation (Tiano, 1994). While wages, and often 
benefits, may have been better in service jobs, the related educational requirements rule them out as an alternative for most poorer women.

It is not always the case that factory employment is a last resort for women. For example, before the restructuring of industry in Hong Kong (China), women, and particularly women with children, expressed a preference for the regularity and fixed working times of factory employment. The service sector jobs in which they found themselves tended to be shift-based and less regular, which made it difficult to organize domestic and childcare arrangements (Chiu and Lee, 1997). Women in Indonesia perceive employment in large-scale export-oriented factories as prestigious, and indeed the wages and conditions are better than in domestic non-export industry and local services. Although educated women aspire to non-manual service sector employment (such as in teaching and tourism), employment in large export-oriented factories seems to offer the best temporary alternative (Chant and McIlwaine, 1995; Grijns et al., 1994).

The crucial issue appears to be the availability of employment alternatives. This is illustrated in a recent attempt to compare the conditions of women workers in traded (export-oriented garment production) and non-traded sectors in Viet Nam and Bangladesh (Kabeer and Van Anh, 2002; Kabeer and Mahmud, 2004). In Viet Nam, where levels of education are much higher than Bangladesh, educated women working in the garment sector express greater levels of dissatisfaction than those with less education. Their preference is for State employment. In Bangladesh, educated women are most likely to be found in the export processing zone (EPZ), where wages are higher and labour conditions much better. They are least likely to express dissatisfaction with their jobs. Women with little or no education are found in smaller, more informal and poorly paid export factories and workshops outside the EPZ, as well as in the informal economy more generally. This group of workers does not differ a great deal from the rest of the informal economy in their levels of dissatisfaction.

Nevertheless, it remains the case that the most widely shared features of women's manufacturing employment across the developing world are longer hours of work and lower wages than men. These differentials have formed the basis of their comparative advantage for export manufacturers. Standing notes that it is precisely in the rapidly industrializing countries in which women's employment has increased the most that wage differentials between men and women are the highest: this differential "may have been both a primary factor in the rapid industrialization of the region and have been perpetuated in part by the character of that industrialization" (1999a: 593). Within individual economies, this pattern seems to hold: Park (1995) notes that in the Republic of Korea the occupations with the highest wage differentials between men and women in the 1970s and 1980s were also the sectors that saw the most rapid increase in women workers. Similarly, in Puerto Rico in the 1960s, the most dynamic new export plants consistently absorbed such a high proportion of women workers that the Government attempted to intervene with tax breaks and other policies in an effort to make men more attractive as employees in export-oriented industry. The strategy had mixed success (see Rios, 1990).

While women's willingness to accept lower wages make them attractive as employees when profitability is based on the low costs of labour in a labour-intensive production process, the shift to a "high road" of new, flexible and technologically and managerially more sophisticated modes of production, in which the cost of labour is less important than 
its quality, presents an important development dilemma for low-income countries. The "high road" is capital-intensive and reduces employment opportunities, particularly for unskilled, primarily female, labour. On the other hand, failure to adopt this strategy may constrain the growth of exports which meet standards for products and services that are being increasingly demanded in advanced countries.

However, as Grijns et al. (1994) note in the case of Indonesia, it is not always clear why new technologies and machines should become the domain of men, as there is rarely any physically heavy work involved or any skills that women could not acquire. In the case of India, the automation of factory work did entail some more hazardous tasks, but as Hensman (1996) notes, it was mainly women's low-skilled jobs that disappeared with automation, while the successes of women in gaining employment security and benefits on a par with men, and in securing maternity and childcare benefits, discouraged employers from recruiting women to the new types of jobs created by automation processes. That is, the reason was not necessarily that women could not perform, or learn to perform, the new tasks required.

\section{Gender and employment in high-value agriculture}

Global agriculture has also undergone significant changes over the past two decades. There has been a relative decline in the export share of traditional agricultural crops (such as grains, coffee and tea), and a rapid increase in high-value agricultural exports (HVAEs) (horticulture, floriculture, rich protein meats and processed food products). In the 1980s, the average annual growth rate in trade of HVAEs ranged from 4 per cent for fresh vegetables and meat to 11 per cent for dairy products and shellfish (Jaffee, 1993). By 2000, HVAEs were estimated to account for approximately two-thirds of total agricultural trade (Dolan and Sorby, 2003). The expansion has come about partly as a result of technological innovation which has allowed the operation of cool chains and transportation, thereby facilitating global exports of more delicate and perishable goods. Trade liberalization has stimulated developing countries in the southern hemisphere to expand into high-value agricultural exports. Countries such as Brazil, Chile, India, Kenya, Mexico, South Africa, Uganda and Zambia now produce high-value agricultural goods as a growing source of agricultural export earnings (Jaffee, 1993; Dolan and Sorby, 2003; Thrupp, 1995).

Another factor in the growth of high-value agricultural exports has been the growth of supermarkets as dominant buyers in global value chains, not just in Europe and the United States, but also in Latin America and Africa. They are able to source across the globe, not through distant markets, but increasingly through direct networks of production and export agents linked into their global value chains. Their position as global buyers gives them immense power within their value chains, and they are able to dictate conditions to suppliers in terms of price, quality, production schedules and requirements. They are also introducing strict technical, environmental and social standards with which suppliers have to comply (Dolan and Humphrey, 2004). Supermarkets have stimulated changes in consumption patterns and demand for the year-round delivery of high quality and often exotic products. Many operate on a 24-hour opening policy and are highly responsive to changing customer needs. An important aspect of changes in shopping patterns and the rise of supermarkets has been the increasing proportion of women who work and contribute to household incomes (Barrientos and Perrons, 1998).

Women have historically worked in agriculture as unpaid family labour, but as agriculture came to be commercialized in many developing countries, women tended to be excluded from formal cash crop production and marketing (Boserup, 1970), although they often continued to work as unpaid family labour (Deere and Leon, 1987). Female labour was less often found in certain traditional agricultural crops (such as livestock and grains), but 
remained prevalent in crops such as tea and coffee, often on estates as well as through family labour in smallholder production. HVAEs have, on the other hand, stimulated a high level of female employment within export production (Barrientos et al., 1999; Collins, 1993; Barron, 1994; Thrupp, 1995; Brandt, 1999; Arizpe and Aranda, 1981; Dolan and Sorby, 2003). This rise in female employment is partly linked to the globalization of production, as discussed above. The level and form of this employment varies considerably by country. Table 2 gives a summary of exports and employment for selected HVAE countries and products. However, official statistics for employment in HVAE production are very unreliable and it is necessary to depend on different estimates for country data.

One of the interesting aspects of the operation of global value chains in agriculture is the fact that an identical physical product in terms of colour, shape, size and taste (such as Thompson seedless grapes, mangetout, carnation flowers) can be sourced on a rotating basis from a range of different countries. Yet the local social and employment context of production can be quite variable, ranging from large commercial estates through to smallholder production. Smallholder production (in which family labour prevails) appears more prevalent in vegetable production, but less so in fruit and flower production, where wage labour is more prevalent, as shown by the example of Guatemala in Table 2. Agricultural global value chains tend to adapt like amoebae to local conditions in order to source products. The nature of employment can also cover a wide range of types of workers, including permanent, temporary, seasonal, casual, contract and migrant workers.

The gender composition of these different categories varies by country and product. In some countries (for example, Chile and South Africa), women are concentrated in temporary and seasonal employment (Barrientos et al., 1999; Barrientos and Kritzinger, 2003). In other countries (such as flower production in Colombia and Kenya), they are more often found in permanent employment, and in Kenya they are usually migrant labour (Dolan and Sorby, 2003; Thrupp, 1995). The use of contract labour is rising in some countries. Anecdotal information and early research findings indicate that the gender composition of this category of workers is more likely to be male, or with men working for longer periods than women, who are brought in when seasonal labour demand peaks (Raynolds, 2001; Barrientos and Kritzinger, 2003; Diaz, 2000). While it is difficult to generalize on the basis of a few case studies, the higher ratio of men in contract gangs does not appear to reflect a particular increase in mechanization or technical skills, as in the case of manufacturing. Instead, it tends to reflect a preference for male labour by contractors, and the fact that contract gangs have to be more mobile than local seasonal labour (usually female), undertaking a wide range of field-based tasks which have normally been considered "male".

\section{Table 2}

Comparison by country of selected high-value agricultural exports (HVAEs)

\begin{tabular}{|c|c|c|c|c|c|}
\hline Country & $\begin{array}{l}\text { Export value } \\
\text { (US\$ million) }\end{array}$ & Market destination & $\begin{array}{r}\text { Level of } \\
\text { employment }\end{array}$ & Gender composition & $\begin{array}{r}\text { Type of } \\
\text { employment }\end{array}$ \\
\hline $\begin{array}{l}\text { Chile } \\
\text { fruit }\end{array}$ & $\begin{array}{r}1,122.2 \\
\text { (grapes only) } \\
676 \\
\text { (fruit \& veg. } \\
\text { Excl. grapes) }\end{array}$ & US, Europe & 336,739 & $\begin{array}{r}52 \% \text { of temporary } \\
\text { workers and } 5 \% \text { of } \\
\text { permanent workers are } \\
\text { women }\end{array}$ & $\begin{array}{r}85 \% \text { temporary } \\
15 \% \text { permanent } \\
\text { wage workers }\end{array}$ \\
\hline $\begin{array}{l}\text { Guatemala } \\
\text { vegetables }\end{array}$ & 1,1216 & North America, EU & $\begin{array}{r}18,000 \\
\text { smallholders }\end{array}$ & $\begin{array}{r}33 \% \text { women in field work } \\
100 \% \text { in processing }\end{array}$ & $\begin{array}{r}\text { Smallholders } \\
90 \% \text { of production }\end{array}$ \\
\hline $\begin{array}{l}\text { Kenya } \\
\text { flowers }\end{array}$ & 110 & $\begin{array}{r}\text { EU (UK, } \\
\text { Netherlands) }\end{array}$ & $\begin{array}{r}40,000 \\
(+4-5,000 \\
\text { smallholders })\end{array}$ & $75 \%$ female & $65 \%$ temporary \\
\hline
\end{tabular}

Source: Dolan and Sorby (2003) 
The gender division of labour within HVAEs can vary by locality and social environment. Men tend to be employed to do tasks deemed more physically demanding, such as heavy field work, some harvesting, irrigation, tractor and forklift driving, and spraying (from which women are often excluded because of health risks). Women tend to be employed for the handling of produce, in harvesting and particularly in packing and processing. This reflects perceptions regarding women's nimble fingers (Elson and Pearson, 1981), as well as the tight labour demand at the height of the season when these types of activity are undertaken (Barrientos et al., 1999).

An important aspect of female employment is its "flexibility". Producers in global value chains face high commercial risks in terms of meeting changing demands and orders from supermarket buyers, and rarely have any assured supply contracts. In addition, they face the natural risks of seasonal production, climatic variation and the vulnerability of crops to pests and disease. Flexible employment allows producers to vary their employment levels on a constant basis. It is normal in many sectors to lay workers off unpaid on rainy days, or to vary (compulsory) overtime so that workers have no advance notice of the hours they will be expected to work. Women are often deemed more "malleable" by producers in accepting these conditions. This is often justified on the basis that women work for "pin money" or a secondary income. Little or no consideration is given to the fact that women working in HVAEs are often key earners in the household, and that they have to juggle sudden changes with childcare and domestic responsibilities.

In addition, much employment in HVAEs is informal. Many workers have no formal employment contract or access to related employment rights or benefits. This is more common among temporary and seasonal workers, and especially prevalent among contract workers. It can even occur with "permanent" workers, who may be employed for 11 months a year and laid off for one month in order to avoid legal employment rights. Examples of this can be found in Chile, Colombia, Kenya and South Africa, to name but a few countries (Barrientos et al., 1999; Barrientos and Barrientos, 2002; Thrupp, 1995; Dolan and Sorby, 2003). Women in particular often face informal employment, and as a result lack employment rights and benefits and have to cope with highly insecure work.

\section{Implications for women in high-value agricultural exports (HVAEs)}

The expansion of employment in HVAE production provides more opportunities for women to take up paid employment in comparison with more traditional forms of agriculture. Despite technological advances, much high-value agricultural production remains labour-intensive, especially in the handling of produce, where female employment is concentrated. There is so far no real evidence that the proportion of women's employment is falling as globalization proceeds, even though women are less often employed in the rising category of contract employment (evidence on this trend is still limited). But the extent to which women are able to gain access to the benefits of HVAE employment largely depends on their work status, which is where gender inequity arises.

A number of studies indicate that the benefits available to permanent workers, both men and women, are relatively better than most casual or flexible forms of work. Permanent workers usually (although not always) have a legal contract of employment, which gives them stability and security of work. Permanent status normally provides better wages (with a year round income that most seasonal and casual agricultural workers do not enjoy) and gives access to related benefits, such as health and social insurance and pensions. In agriculture, non-wage benefits are common in some countries, especially where workers live on the farm or estate. These can include housing, childcare, social provision and transport. Permanent workers are also more likely to enjoy the right to freedom of association, although rates of trade union membership in export agriculture are generally low (Falabella, 1993; Murphy, 1995). 
The problems facing flexible agricultural workers, especially those working on an informal basis, are legion. They often have no contracts of employment (even for the season) and their terms and conditions of work are based on verbal agreement, with little information provided. They face high levels of instability and insecurity in their employment. Wages (often paid on a piece rate) can vary on a daily or weekly basis, depending on seasonal demand. They often receive no pay when production stops because of the weather, even if they have come to work. They are frequently forced to work long hours of overtime, often with no additional pay beyond their piece rate. Overtime in packing houses, in particular, can be decided upon at very short notice to meet variable orders from global buyers, so that workers do not know in the morning what time they are likely to finish in the evening. This can make childcare arrangements extremely difficult, particularly for women. Informal agricultural workers receive no health and social insurance, and compensation for workrelated injury is often avoided. Flexible, and especially informal workers, fear that if they make any complaints or join a union, they may lose their jobs. Women often fall prey to verbal abuse and sexual harassment by male supervisors, who are normally the arbiters of whether they should be re-employed (Barrientos et al., 1999; Dolan and Sorby, 2003; Thrupp, 1995; Barrientos and Kritzinger, 2003; Brandt, 1999). Flexible, and especially informal agricultural workers, are thus in a highly vulnerable position.

Gender inequity arises because women are more likely than men to be in temporary and seasonal work, with fewer employment benefits. However, there are variations in specific products and categories of work. Flower production in greenhouses is mainly carried out all year round, with high levels of female employment, and in some countries, such as Ecuador, they receive full benefits. In others, they are not in such a good position, but there are moves to integrate them, for example in Kenya (Dolan and Sorby, 2003). Women tend to be employed in packing houses in most sectors. Packing house workers often receive relatively good wages compared to field workers, and are more likely to have access to the employment benefits and rights to which they are entitled as temporary workers (their work may therefore be flexible, but it is less often informal) (Barrientos et al., 1999; Dolan and Sorby, 2003; Barrientos and Kritzinger, 2003). At the other end of the spectrum, contract workers often experience the most flexible and informal employment, but there appears to be a higher concentration of male labour among such workers.

In agriculture, one issue that would appear to affect workers across the continuum is health and safety. Problems arise especially from the use of pesticides and other chemicals in the production process. This is a particular problem for workers in confined spaces, such as greenhouses and packing houses, where exposure tends to be high and the workforce is largely female. There is evidence to suggest that health and safety procedures in relation to the handling and use of pesticides and chemicals are often lax or violated. The effects of chemical exposure can include skin irritation, respiratory problems, nausea and dizziness. The longer-term effects can be more serious, including a higher risk of serious illness and, in the case of women in particular, reproductive damage, including damage to unborn children (malformed foetuses, higher instances of miscarriage) (Medel and Riquelme, 1994; Reeves et al., 1999).

Despite the problems faced by women agricultural workers in global production, especially those with flexible and informal work, many still express the preference to have a job compared to the alternatives. Paid agricultural work provides increased independence within the household, the ability to contribute to household income and greater socialization. It also offers access to government and community-support programmes, which would otherwise be inaccessible (Barrientos et al., 1999; Dolan and Sorby, 2003; Venegas, 1992 and 1993; SERNAM, 2001; Barrientos and Barrientos, 2002). As a result, even where there are negative work attributes, there are also many positives and women may still prefer this work to the alternatives. 
In brief, HVAEs have provided women with paid employment opportunities in many developing countries which have been able to lock into this type of export agriculture. Women have long worked in agriculture as unpaid family labour, but have only had limited employment opportunities in traditional agricultural exports. The nature of female employment varies by location and product. Some enjoy more formal permanent work, but many are in more informal temporary and seasonal employment. While they have the advantage of access to employment and income generation opportunities, which were often previously unavailable to them in rural areas, the work does not necessarily come with the associated labour rights or benefits.

\section{Enhancing female employment in global production: Policy implications}

Female employment in global production is significant in certain sectors of manufacturing and agriculture. There has not only been a "feminization" of the labour force, but also a change in the gender dimension of global employment. Women's earnings are often a crucial element in household survival: they are not "secondary earners", as depicted in more traditional employment models, and they can accrue many advantages from their employment. But women are often concentrated in flexible and informal work, and gender constraints often limit their ability to gain access to work opportunities and benefits. This concluding section considers some of the key constraints upon women's ability to take up employment in global production and to participate in the labour market on more equitable terms. The issues considered include: (a) How can policies be developed that address the combined productive and reproductive roles of women working in global production? (b) How can female employment in global production be enhanced in terms of increasing the opportunities and quality of women's work? (c) What role can the various stakeholders play in enhancing gender equitable employment in global production?

These are important policy questions. The United Nations Millennium Summit held in 2000 brought together key actors in the development field, governments as well as donors, to consider key priorities for the first phase of the new millennium, and it culminated in the adoption of the Millennium Development Goals. These include eradicating world poverty, achieving universal primary education, promoting gender equality and the empowerment of women, reducing child mortality, improving maternal health, combating disease, achieving environmental sustainability and developing a global partnership for development. Women's access to paid work is mentioned in relation to the goal of women's empowerment. However, evidence from different parts of the world suggests that policies to promote women's productive activity by simultaneously addressing their reproductive responsibilities offer a powerful potential to maximize the possible synergies and minimize the trade-offs between poverty eradication and human development, while at the same time empowering women (Kabeer, 2003). These aspects need to be extended into policies on support of women's employment in global production.

\section{Childcare}

One important point to bear in mind when thinking through policies to promote both the quantity and quality of female employment is that women workers differ in significant ways from male workers. The increasing involvement of women in paid work suggests that the older "male breadwinner household" needs to be replaced by a multiple breadwinner household. However, women's continued responsibility for domestic work and childcare suggests that they need policies to support them in their dual responsibilities. Such issues as childcare facilities, day-care centres, accessible schooling, maternity leave and health insurance are likely to feature more highly on their list of priorities than they do for men. The policy challenge is to work out how such measures can be initiated and financed and the key actors who should be responsible. 
The single most important factor which acts as a barrier to women's ability to participate as full economic actors in the global economy is their domestic responsibilities, and for a large subgroup, their childcare responsibilities. The childcare constraint appears to operate across contexts which are otherwise very different. In some parts of the world, it is one of the determinants of the gender gap in earnings and promotion prospects; in others, it also differentiates their life cycle pattern of labour force participation; while in yet others, it determines where they are located in the labour market. It differentiates the occupational trajectories of men from women, as well as the opportunities available to women with children and those without them. It shapes the ex ante expectations of employers regarding the labour force attachment of women workers and hence their willingness to invest in them. It also shapes the expectations of women workers. Faced with a working environment that makes no allowances for their mothering responsibilities, women may be less willing to invest in their own human capital. In addition, some women, knowing the difficulties of combining paid work and childcare, withdraw into self-employment once they have children. Such withdrawal often signals a drop in family income. Others, who cannot forego this income, leave their children in a variety of different arrangements, not all of which are conducive to their welfare. As one of the main factors differentiating the labour of women and men, the reliable provision of childcare is critical to "levelling the playing field", as well as to ensuring the welfare of children. Box 1 gives examples of childcare provision in Bangladesh and India.

Box 1
Examples of childcare provision for women workers
Bangladesh
In Bangladesh, Phulki, a women's NGO, has worked with employers and employees to set up childcare
centres within a number of export garment factories. These are financed by contributions from employers,
employees and an initial subsidy from a donor agency. Phulki has used a variety of arguments to persuade
employers that it is in their interests: the "business" case of less absenteeism; the legal argument of
compliance with national laws; and the humanitarian aspect of the welfare of mothers and children. In the
course of lobbying the Government, it also managed to persuade it to introduce childcare facilities for its
own employers in the Government Secretariat (Interview with Suraiya Hussain, 2001).
India
The organization Mobile Crèches was set up in 1969 in India to meet the needs of construction workers in
the urban informal economy. Childcare centres are set up at construction sites to provide day care,
informal education, recreation, basic nutrition and breastfeeding facilities. The building contractor
contributes accommodation and basic utilities. The organization has been funded by Concern India
Foundation, the Central Social Welfare Board, as well as a number of corporate bodies and individual
donors.

A second important point, relevant mainly to manufacturing, relates to the widely observed displacement of female labour as factories move up the value chain or into higher technology production processes. This may be linked to the point made earlier about the incentives of employers to invest in the long-term accumulation of the human capital of women workers or to gender disparities within the educational system, which deny women access to certain skills. However, as long as this pattern is not challenged, women will remain confined in lower value added jobs in which conditions are likely to be far more exploitative, and they will lose out when upgrading leads to a higher demand for more skilled labour.

Sustained efforts have to be made, on the one hand, to retain women within the educational sector and, on the other, to promote their participation in more technical subjects which equip them better for the marketplace. In addition, vocational training can ensure the continuous upgrading of skills to reflect changing skill requirements on the labour market. 
Such measures can contribute to greater stability in women's labour force attachment as sectors or firms move into higher value added stages of production. Finally, to complement investments in skills and human capital, governments should also play a role in establishing schemes, such as employment exchanges, to help to find work for retrenched workers and coordinate their skills training.

Agriculture is generally less capital intensive than manufacturing, but some areas of agro-export production still require advanced technical skills. Women tend to be excluded from some of the more capital-intensive tasks, such as the operation of computerized irrigation systems, driving tractors and some of the more skilled tasks in the cool chain system and management. However, more progressive employers are beginning to realize the advantages of multi-skilled teams in which both women and men are able to carry out the same sets of tasks. Evidence from case studies also points to the greater use of women by some employers in more senior technical and managerial positions as a means of changing employment culture and raising productivity through more innovative working patterns. However, a significant barrier to the advancement of women, both in terms of taking up skilled work and their access to more senior managerial positions, is the lack of training that is available to them. There needs to be a more systematic extension of the training provided by governments and employers, and of training schemes supported by multilateral donors, with particular focus on enhancing the opportunities of women.

\section{Labour standards}

Globalization has brought workers in countries at very different levels of development into direct competition with each other, making the maintenance of labour standards an issue of international concern. The ILO's core Conventions have been widely ratified and are important in addressing gender inequalities. The Equal Remuneration Convention, 1951 (No. 100), and the Discrimination (Employment and Occupation) Convention, 1958 (No. 111), are those most directly concerned with gender equity in relation to pay and access to employment, training and working conditions, but the right to organize and to engage in collective bargaining are also important preconditions for fighting discrimination at work.

However, implementation of Conventions depends on national governments. Even where Conventions are formally enshrined in national law (which is still lacking in some countries), the gender gap remains a significant issue, both in relation to pay and women's access to higher skilled jobs in most sectors of global production. Enforcement of these Conventions in the context of global production requires a more proactive policy approach across countries by international organizations, governments, employers, trade unions and non-governmental organizations (NGOs).

The challenge for the ILO is the enforcement of standards in a global context. One suggested route would be through trade agreements. However, apart from being highly contested, particularly by developing countries, this route has practical limitations. Its main focus is on the formal traded sector. The reality today is that labour markets are characterized by a continuum in which the formal shades into the informal and women move between jobs in the traded and non-traded economy. Globally enforced labour standards may improve jobs in the traded sector, but they are only likely to address a very small (formal) segment of this sector. They will do little for those at the informal end of the traded continuum, and even less for those in the non-traded informal economy, and may end up increasing the incentives to informalize. There is a danger that they will simply serve to set up a privileged enclave for the few, while curtailing employment opportunities for the many (Kabeer, 2004; Hale, 2002; Bardhan, 2000). 


\section{Voluntary initiatives}

Multinational companies also have a responsibility to promote the welfare of their workers and to respect their rights. In this respect, voluntary initiatives addressing employment conditions would go some way towards meeting international concerns. At a minimal level, such voluntary initiatives are reflected in the adoption by corporations and global buyers of codes of conduct covering employment along their value chains. Self-defined company codes, however, do not necessarily incorporate core ILO Conventions or address gender rights, and have no independent means of verification. Increasingly, multistakeholder initiatives, either at a sectoral or cross-sectoral level, involving companies, trade unions and NGOs, are being developed. Multi-stakeholder initiatives are more likely to incorporate core ILO Conventions in their codes of practice and to involve some form of independent verification of their application. Two of the more comprehensive initiatives of this type are Social Accountability International in the United States and the Ethical Trading Initiative in the United Kingdom, both of which incorporate the principles of nondiscrimination and equal pay.

To be effective in addressing gender and the labour rights of workers, such initiatives need to apply to both formal and informal economy. Women workers in informal work are increasingly linked to global production, but this is where employment conditions are often poorest and labour rights are abused, and therefore where codes of conduct are most needed. However, codes are less able to reach the base of complex supply chains, where women in informal work (such as homeworkers and contract labour) are often located. Moreover, company and multi-stakeholder codes are often weak on gender issues related to employment, such as childcare and the reproductive health of workers (Barrientos et al., 2003). These initiatives need to involve local stakeholders, including women's interest groups, if they are to reach out to more marginal workers, such as women in the informal economy. They need to cover wider gender issues, such as childcare and reproductive rights, if they are to address the underlying causes of gender inequality and discrimination in the labour force in global supply chains. The ILO and national governments can play a role in encouraging the development of credible independent certification bodies and in ensuring that labour and gender rights are genuinely observed.

Voluntary initiatives may go some way towards improving gender equity in global employment. But ultimately they are not a substitute for the implementation of adequate national legislation and the representation of workers themselves as a means of enforcing more equitable employment conditions in global production.

\section{National legislation}

ILO Conventions represent the basic minimum that commands consensus in the international community. Countries may need to review their labour laws, many of which were developed in an earlier and more protected era when the workforce was largely male, and to agree on certain minimum standards that they are committed to enforcing. It is at the national level that it should be possible to take into account local conditions and possibilities. And by taking into consideration gender inequalities and inefficiencies in the national economy, it should also be possible put in place appropriate gender-responsive employment policies in support of gender-equitable employment in global production. To be effective, government policies and initiatives need to be backed up by machinery for enforcement, as well as mechanisms for holding the State accountable. Singh and Zammitt (2000: 73) suggest that the ILO could assist in improving labour standards by:

- helping developing countries to estimate the cost of implementing particular labour standards and the type of assistance required;

- $\quad$ providing operational support to developing countries in this field, and acting as the channel for assistance for this purpose from advanced countries; and 
- $\quad$ giving high priority to developing policy proposals to translate the notion of decent work into concrete policies and practice.

\section{Organization}

However, external assistance to governments to improve regulation and enforcement may not be adequate without organized pressure from workers at both the local and international levels. Clearly, the ILO Conventions on freedom of association and the right to collective bargaining are an important precondition. However, in contexts in which there is a large pool of reserve labour that can replace workers if they are dismissed, it is not at all clear how easy it is for women workers, who have limited options in the labour market, to engage in organized action in defence of their rights. Moreover, collective bargaining can best be implemented in the context of full-time formal employment, whereas many women in the global economy are in informal work.

One relatively new means of supporting the ability of workers to organize in the context of global production chains are the international framework agreements (IFAs) that have been established by global union federations and multinational enterprises (MNEs). These are negotiated between a transnational company and the trade unions representing its workforce at a global level. They are designed to ensure fundamental workers' rights in all the company's workplaces. The central feature of all IFAs is a clear commitment by the company to respect core labour standards, but most also include additional agreements relating to working conditions, the environment and a living wage (Spooner, 2003). The first IFA was signed by the International Union of Foodworkers and Danone in 1989, and 21 IFAs have now been concluded. Given significant female employment in many global industries, it is important that these address gender issues, which could be extended through the inclusion of the reproductive rights of workers.

The fact that global production increasingly includes informal workers raises significant challenges in relation to their organization. But new forms of organization have emerged among women workers in some countries (Rowbotham and Mitter, 1994). The SelfEmployed Women's Association (SEWA) in India offers a model of a different way of organizing that speaks to the needs and organizational potential of women in the informal economy (see Box 2). An important aspect of SEWA is that it addresses both work and social issues. It therefore provides a blueprint for possible forms of organization covering a range of the needs of informal workers linked to the global economy. 


\section{Box 2}

\section{Self-Employed Women's Association (SEWA), India}

SEWA is one of the few trade unions in India for workers in the informal economy. The traditional trade unions in the country mainly represent workers in the formal economy, most notably in the public sector. Informal workers in India still have a low profile and are under-represented at the state and national levels.

SEWA builds member solidarity around common causes and campaigns for workers' basic needs. This falls comfortably within the framework of SEWA's tradition of campaigning for workers' rights within the broader field of human rights generally. Campaigns are organized at the grassroots, state and national levels, as well as internationally.

SEWA has almost a quarter of a million women members in total $(215,234$ in 1999).

In recent years, SEWA has adopted an integrated approach to eradicating poverty. According to SEWA in its 1999 report, this consists of:

- $\quad$ organizing for collective strength, bargaining power and representation on committees and boards at the district, state, national and international levels;

- $\quad$ capital formation at the household level to allow women in their own right to have access to financial services, such as savings, credit and insurance, and to build and develop property, including land, housing and workshops;

- capacity building through education, information and training, to allow women to run their own businesses and compete in the marketplace by giving them access to market facilities;

- $\quad$ social security based on the principles of dignity of labour and "work security". For SEWA, the concept of work security means simultaneously addressing the multiple risks of ill health, loss of assets, unforeseen calamities, death and disability, and child-bearing, with their attendant economic and social effects. Any one or a combination of these factors may keep women workers in poverty.

Source: $\quad$ ILO (2001).

One set of lessons that emerge from historical experience is that unless marginalized groups can be mobilized to act on their own behalf, any form of intervention intended to address their interests can be subverted by those in power. Furthermore, the male dominance of traditional organizations has ensured that women's priorities, both as women and as workers, have tended to be sidelined. Alongside the various interventions undertaken by the State, corporations, trade unions and international agencies, attention therefore needs to be paid to promoting the organizational capacity of women workers, both within traditional labour organizations, such as trade unions, and through newer forms of collective action (see contributions to Naples and Desai, 2002; Chhachhi and Pittin, 1996; Deyo, 1990; Kabeer, 2004). Finally, the voices of poorer women workers in developing countries remain absent from global forums. Organizations such as Women in Informal Employment Globalizing and Organizing (WIEGO) are attempting to correct this, but attention also needs to be given to strengthening other networks.

\section{Social floor}

Increasing attention is being paid to the idea of a basic social floor for all workers, regardless of where they are located. While in Europe this has taken the form of calls for a basic citizen's income (Standing, 1999), there are other possibilities that can be explored in the context of the developing countries. These might include micro-finance programmes, the public distribution of basic foods, State-subsidized health insurance and public works programmes. The new President of Brazil is talking about a zero hunger programme to be put in place in North-East Brazil. The main point about a universal social floor is that it moves away from increasingly anachronistic distinctions between traded and non-traded sectors and formal and informal work to an acknowledgement of the interdependence between the will to work for decent living conditions in the traded sector and the 
conditions that prevail in the non-traded economy. Box 3 gives an example of an innovative health insurance scheme (SHINE) in the Philippines.

\section{Box 3}

\section{Social health insurance in the Philippines}

In the Philippines, support systems such as health insurance cater mainly for the formally-employed sector. Approximately 50 per cent of health-care expenditures are still paid out of private pockets and the national budget for health is mainly sourced from a regressive tax system that is unfair to the poor. Although approximately 50 per cent of the population are covered by the various health insurance schemes, only 10 per cent of all health care expenditure was covered by these schemes in 1991 and this share has not significantly increased since then. At the national level, the sole compulsory insurance with limited benefits (Medicare I) only covered formal employees in the private and public sectors. Although voluntary membership is offered, the percentage of voluntary members is quite low. The poor are typically reduced to charitable services for the provision of health care.

In the early 1990s, the Philippine Department of Health (DOH) felt that the limitations of the publicly provided health care system required the adoption of new approaches. Through the Health Finance Development Project and the experience of prior community initiatives, the idea of a social health insurance, through which accessibility and affordability would be pursued simultaneously, was given high priority by the DOH. This culminated in the enactment of the National Health Insurance Law, 1995. The Social Health Insurance Networking and Empowerment (SHINE) project was proposed as an innovative instrument to overcome the inequities and inefficiencies of the established system. It is a bilateral technical cooperation project undertaken jointly by Germany, represented by the German Agency for Technical Cooperation (GTZ), and the Philippines, represented by the Department of Health (DOH) and the Philippine Health Insurance Corporation (PhilHealth).

The concept of SHINE rests on two major principles:

- $\quad$ to build up the national health insurance scheme;

- $\quad$ to simultaneously support local self-help initiatives at the community level, which attempt to protect the poorest from health risks (see WIEGO).

The self-help initiatives are focused on women, their contribution to the health of the family and their importance in decision-making regarding local and family resources. The primary aim is to support local community-based organizations striving for self-financing, sustainable membership and administration.

\section{Stakeholders' roles}

Certain roles clearly fall within the responsibility of specific stakeholders. Other interventions may be developed more effectively through collaboration between different stakeholders. However, all regulations, action and accountability initiatives should be reexamined from a gender perspective, focusing on how to enhance gender equity in employment in a global context. In particular, emphasis should be placed on supporting both the productive and reproductive roles of women workers and upgrading their employment. Some of the ways in which this can be done are indicated below:

\section{(a) Government:}

- government regulation that extends labour protection to formal and informal women workers;

- programmes that support training and skills provision to "upgrade" women workers;

- State support for childcare and social provision for women workers (formal and informal);

- basic income and social protection for all workers (including women). 
(b) Private sector corporations:

- codes of conduct and employment policies that incorporate non-discrimination and equal pay for women workers;

- $\quad$ codes of conduct and employment policies that support informal workers;

- MNEs and local firms that introduce "family-friendly" employment policies in their value chains and employment.

(c) Trade unions:

- positive recruitment and representation of women workers;

- international framework agreements (IFAs) incorporating gender equity standards;

- labour organizations of informal workers to represent their interests as part of the wider labour movement and to negotiate with the relevant authorities to safeguard their members' rights.

(d) NGOs:

- $\quad$ support and information for women workers (particularly informal) within global production systems;

- campaigns and advocacy around issues that affect women and men workers in global production (such as lack of reproductive rights, discrimination);

- community support programmes that reach women workers.

An example of multi-stakeholder policy development is provided by an initiative led by the Chilean Government for temporeras (women seasonal workers) in the Chilean fruit sector. The Government set up four (and a half) commissions to examine the related issues of health and safety at work, childcare, pesticides and training. In addition, the Ministry of Labour attempted parallel discussions on labour conditions (this is the half commission). These commissions involved ministries and organizations linked to the Government, as well as private sector organizations and workers' representatives (see Box 4). Setting up the commissions reflected the need for integrated policies cutting across productive and reproductive issues, including childcare, and involving different actors in the formulation of their provisions. To improve the lives of working women in global production, these types of combined initiatives are required across different sectors and countries. 


\section{Box 4}

\section{Commissions set up to support temporary agricultural workers in Chile}

In January 2001, SERNAM (the women's ministry) set up four and a half tripartite commissions with the participation of employers, workers' representatives and government departments to consider ways in which the welfare of temporary workers in horticulture could be improved (SERNAM, 2001). This followed a strong lead and invitation from the President of Chile, Ricardo Lagos. The four commissions cover: health and safety at work, led by the Health Ministry; childcare, led by SERNAM; pesticides, led by the Ministry of Agriculture; and training, led by SENCE (the training agency). In addition, the Ministry of Labour attempted parallel discussions on labour conditions (this is the half commission). The representation of employers includes the Sociedad Nacional de Agricultura (a longstanding landowners' association), the Federacion Gremial de Productores de Fruta (the fruit producers' association) and the Asociación de Exportadores de Chile (the exporters' association). Participation by workers was patchy and limited to the commission on pesticides. The commissions met in 2001 and developed plans of action in the areas under their remit. The labour conditions commission did not get off the ground. As a whole, the commissions have made positive advances in generating support and consensus on policy by stakeholders and have had an important effect in coordinating policy efforts among the different government agencies. At the same time, a number of difficulties have been identified. It was difficult to ensure worker representation in all the commissions, policies adopted by the commissions can be more effectively implemented in those areas under government control, but need further work to implement them on the ground (for example, crèches need cooperation at the local level from producers and national and local government agencies). Employers are reluctant to engage in discussions on labour conditions, largely because of the strong veto that they exercise in practice in this area of government policy.

Source: Barrientos and Barrientos, 2002.

\section{Multi-stakeholder initiatives}

There is increasing realization that, in the context of a more liberalized global economy, effective policy support and development requires the joint engagement of different stakeholders. Cross-partnership initiatives affecting women's employment in global production have been developed at both the national and international levels, some examples of which have been given above. Multi-stakeholder initiatives need to be built on and extended into even more innovative areas combining employment protection and social provision that is accessible to both women and men, formal and informal workers in the global economy. This requires breaking down existing boundaries between stakeholders and recognition by all the stakeholders of their own limitations and their obligations. Neither the State nor the private sector alone can be effective in addressing labour rights and social provision for women and informal workers. More can be achieved through partnership and joint action in collaboration with trade unions and NGOs than through individual action by separate stakeholders. This requires ensuring that there is a gender focus to all policy provisions and addressing the interests of women and informal workers.

\section{Multilateral initiatives}

In a global economy there are a range of multilateral organizations whose activities and initiatives have implications for gender and employment. The ILO is one of the longest standing international organizations incorporating different stakeholders through its tripartite structure. It has a central role to play in the extension of policies aimed at supporting female employment in the global economy. It can do this both by enhancing gender equity in the implementation of its Conventions and its other activities, and by supporting new partnership-based initiatives that focus on gender in global employment. These can include: 
- ensuring that decent work and international labour standards enhance female employment and address gender discrimination;

- providing support and advice to governments, employers and trade unions, and helping build institutions that ensure accountability for gender equity goals;

- working in partnership with other organizations at the international and national levels to develop programmes and initiatives that support women and men workers on a gender-equitable basis in a global economy.

One example of a multilateral initiative relevant to gender and global employment which involves a number of stakeholders and institutions is the United Nations Global Compact, which is based on collaboration between companies and civil society organizations, and includes the participation of international organizations such as the ILO. The Global Compact specifically includes labour standards (based on the ILO's core Conventions) in its provisions and is thus an important initiative that is able to address issues of nondiscrimination and equality in global employment. It would be interesting to assess the effectiveness of the Global Compact in achieving its goals with regard to gender issues (such as through a gender audit of its activities). This would also help to raise awareness of the need to address gender issues in relation to global employment and could assist in identifying further initiatives to enhance the position of women in the global labour force.

Traditionally, organizations such as the European Union, the World Trade Organization (WTO) and the International Monetary Fund (IMF) have had a very specific focus on political, trade and financial issues at the regional or international level. However, there is increasing recognition (prompted partly as a response to the Millennium Development Goals) that these institutions do not operate in a vacuum and that their policies need to promote pro-poor development. This is reflected by increased concern for trade and poverty, for example in the Doha Round of the WTO. Trade reform (such as tariff liberalization and trade agreements) at the international, regional and national levels has direct implications for employment, much of which is now female in some global production sectors. Employment is an important linkage mediating trade and poverty, and a significant proportion of the poor are women. There is therefore a gender dimension to the linkage between trade and poverty. Enhancing the quantity and quality of employment for women in global production could be an important aspect of the design of pro-poor trade policies which has to date been largely overlooked in regional and international trade discussions and agreements.

\section{Conclusion}

Global production has led to significant increases in women's employment in certain export sectors and to changes in gender employment relations. However, women remain constrained in their ability to gain access to job opportunities and quality work by their combined productive and reproductive responsibilities. Globalization has brought to the fore actors in the marketplace which, combined, can address productive and reproductive activities, paid and unpaid work, and which therefore straddle economic growth and human development. Their presence challenges previous interventions intended to promote workers' welfare and rights which had been premised on the model of a fully-employed primary breadwinner in formal employment. The response has to be multi-pronged to take account of these dual responsibilities. It also has to be sensitive to the fact that women are generally disadvantaged in the labour market, partly because of overt discrimination, but also because of their dual responsibilities. It is unlikely that any single stakeholder, however active, will be able to address this challenge on its own. But by building on the synergies of acting together and drawing on a new range of organizations, such as those of informal workers, it may be possible to ensure that women participate in the global economy on more equal terms. 



\section{Bibliography}

Arizpe, L. A., and Aranda, J. 1981. “The 'comparative advantages' of women's disadvantages: Women workers in the strawberry export agribusiness in Mexico", in Signs, 7(2): 453-473.

Bardhan, P. 2000. Social justice in the global economy. ILO Social Policy Lecture, 1-6 September, University of the Western Cape, South Africa. (Also available at http://www.ilo.org/public/english/bureau/inst/papers/sopolecs/bardhan/ visited on 15 March).

Barrientos, A. and Barrientos, S.W. 2002. Extending social protection to informal workers in the horticulture global value chain. Washington DC, World Bank.

Barrientos, S., Dolan, C. and Tallontire, A. 2003. "A gendered value chain approach to codes of conduct in African horticulture", in World Development. 31(9): 1511-1526..

Barrientos, S. and Kritzinger, A. 2003. "The poverty of work and social cohesion in global exports: The case of South African fruit", in Chidester, D. (ed.), Beyond solidarity? Globalization and social cohesion in South Africa. South Africa, Human Resources Research Council (HSRC) and National Economic and Labour Council (NEDLAC).

Barrientos, S. and Perrons, D. 1999. "Gender and the global food chain: A comparative study of Chile and the UK," in Afshar, H. and Barrientos, S. (eds.), Women, globalization and fragmentation in the developing world. Basingstoke, Macmillan.

Barrientos, S., Bee, A., Matear, A. and Vogel, I. (1999). Women and agribusiness: Working miracles in the Chilean fruit export sector. Basingstoke, Macmillan.

Barrón, A. 1994. "Mexican rural women wage earners and macro-economic policies," in Bakker I. (ed.), The strategic silence: Gender and economic policy. London, Zed Books.

Bhattacharya, D. and Rahman, M. 1999. Female employment under export-propelled industrialisation: Prospects for internalising global opportunities in the apparel sector in Bangladesh. United Nations Research Institute for Social Development (UNRISD), Occasional Paper No. 10.

Boserup, E. 1970. Woman's role in economic development. New York, St. Martins Press.

Brandt, D. 1999. Women working the Nafta food chain: Women, food \& globalization. Toronto, Second Story Press.

Brinton, M. C., Lee, Y. and Parish, W. L. 1995. "Married women's employment in rapidly industrializing societies: Examples from East Asia", in American Journal of Sociology, 100 (5): 1099-1130.

Chant S. with Craske, N. 2002. Gender in Latin America. London, Latin American Bureau.

Chant, S. and McIlwaine, C. 1995. Women of a lesser cost: Female labour, foreign exchange and Philippine development. London, Pluto Press.

Chen, M. and Sebstad, J., with O'Connell, L. 1999. "Counting the invisible workforce: The case of homebased workers", in World Development, 27 (3): 603-610.

Chhachhi, A. 1999. Gender, flexibility, skill and industrial restructuring: The electronics industry in India. The Hague, Institute of Social Studies. Working Papers Series No. 296.

Chhachhi, A. and Pittin, R. (eds.). 1996. Confronting state, capital and patriarchy: Women organizing in the process of industrialization. Basingstoke, Macmillan.

Chiu, S. W. K. and Lee, C. K. 1997. "After the Hong Kong miracle: Women workers under industrial restructuring", in Asian Survey. 37 (8): 752-770.

Chow, E. N. 2002. Transforming gender and development in East Asia. London, Routledge.

Collins, J. L. (1993). "Gender, contracts and wage work: Agricultural restructuring in Brazil's São Francisco valley", in Development and Change. 24(1): 53-83. 
Davin, D. (2001). The impact of export-oriented manufacturing on Chinese women workers. Paper prepared for the UNRISD project on globalization, export-oriented employment for women and social policy. Geneva.

Deere, C. D. and Leon, M. (eds.). 1987. Rural women and state policy: Feminist perspectives on Latin American agricultural development. Boulder, Westview.

Deyo, F. C. 1989. "Labour systems, production structures, and export-manufacturing: The East Asian NIC's", in Southeast Asian Journal of Social Science. 17(2): 8-24.

----. 1990. "Economic sheltering and working class formation in the East Asian NIC's", in Labour, Capital and Society. 23(2): 218-38.

Diamond, N. 1979. "Women and industry in Taiwan", in Modern China. 5(3): 317-340.

Diaz, E. 2000. Suministro de trabajadores en la fruticultura: El caso de los temporeros y temporeras en la VI Region. Santiago, Mujer y Trabajo.

Dolan, C. and Humphrey, J. 2004. "Changing governance patterns in the trade in fresh vegetables between Africa and the United Kingdom", in Environment and Planning. 36(3), March: 491509.

Dolan, C. and Sorby, K. 2003. Gender and employment in high-value agriculture industries. Washington DC, World Bank.

Elson, D. 1996. "Appraising recent developments in the world market for nimble fingers', in Chhachhi, A. and Pittin, R. (eds.), Confronting state, capital and patriarchy: Women organizing in the process of industrialization. Basingstoke, Macmillan.

Elson, D. and Pearson, R. 1981. "Nimble fingers make cheap workers: An analysis of women's employment in third world export manufacturing”, in Feminist Review. 7, Spring: 87-107.

Falabella, G. 1993. "Reestructuración y respuesta sindical: La experienca en Santa María, madre de la fruta chilena", in Economia \& Trabajo. 1(2): 239-260.

Fiala, R. and Tiano, S. 1991. "World views of export processing workers in northern Mexico: A study of women, consciousness, and the new international division of labor", in Studies in Comparative International Development. 26(3): 3-27.

Fussel, M. E. 2000. "Making labour flexible: The recomposition of Tijuana's Maquiladora female labour force", in Feminist Economics. 6(3): 59-80.

Ghosh, J. 2001. Globalisation, export-oriented employment for women and social policy: A case study of India. Paper prepared for the UNRISD project on Globalisation, Export-oriented Employment for Women and Social Policy. Geneva, UNRISD.

----. 2000. Rules of international economic integration and human rights. Human Development Report Office, Background Paper. New York, UNDP. (Available at www.undp.org/hdro/papers/ocpapers/occ.htm visited on 9 March)

Grijns, M., Smyth, I., Van Velzen, A. and Mac Hfud, S. (eds.). 1994. Different women, different work: Gender and industrialisation in Indonesia. Aldershot, Avebury.

Hale, A. 2002. "Trade liberalisation in the garment industry: Who is really benefiting?", in Development in Practice. 12(1): 33-44.

Heeks, R. and Slamen-McCann, A. 1996. "Job and skill impacts of new technology in the East Asian electronics industry: Some aspects of recent literature", in Science, technology and Development. 14(3): 50-71.

Hensman, R. 1996. "Urban working-class women: The need for autonomy", in Chhachhi, A. and Pittin, R. (eds.), Confronting state, capital and patriarchy: Women organizing in the process of industrialization. Basingstoke, Macmillan.

Hutchison, J. 1992. "Women in the Philippines garments exports industry", in Journal of Contemporary Asia. 22(4): 471-489. 
ILO. 2002. Decent work and the informal economy. International Labour Conference, 90th Session, Report VI. (Available at www.ilo.org/public/english/standards/relm/ilc/ilc90/pdf/rep-vi.pdf visited on 9 March 2004)

----. 2001. Women organizing for social protection: The Self-Employed Women's Association's integrated insurance scheme, India. Strategies and Tools against social Exclusion and Poverty Programme (STEP). Geneva. (Available at www.ilo.org(public/english/protection/secsoc/publs/sewa2.htm visited on 9 March 2004)

----. 1996. Economically active population, 1950-2010. Geneva.

Jacka, T. 1990. "Back to the wok: Women and employment in Chinese industry in the 1980s", in Australian Journal of Chinese Affairs. 24: 1-23.

Jaffee, S. 1993. Exporting high-value food commodities: Success stories from developing countries. World Bank Discussion Paper 198. Washington DC, World Bank.

Kabeer, N. 2004. "Globalization, labour standards and women's rights: Dilemmas of collective (in)action in an interdependent world", in Feminist Economics. 10(1): 3-31.

----. 2003. Gender mainstreaming in poverty eradication and the Millennium Development Goals: Handbook for policy makers and other stakeholders. London, Commonwealth Secretariat.

----. 2000. The power to choose: Bangladeshi women and labour market decisions in London and Dhaka. London, Verso.

Kabeer, N. and Anh, T. Van. 2002. Global production, local markets: Gender, poverty and export manufacturing in Viet Nam. IDS, mimeo.

Kabeer, N. and Mahmud, S. 2004. "Gobalisation, gender and poverty: Bangladeshi women in export and local markets", in Journal of International Development. 16(1): 93-109.

Karshenas, M. 1997. Economic liberalisation, competitiveness and women's employment in the Middle East and North Africa. University of London School of Oriental and African Studies, Department of Economics Working Paper No. 79.

Kelegama, S. and Wignaraja, G. 1992. "Labour absorption in industries: Some observations from the post-liberalization experience of Sri Lanka", in Industry and Development. 31: 119-144.

Kopinak, K. 1995. "Transitions in the maquilization of Mexican industry: Movement and stasis from 1965 to 2001", in Labour, Capital and Society. 28(1): 68-94.

Lund, F. and Srinivas, S. 2000. Learning from experience: A gendered approach to social protection for workers in the informal economy. Strategies and Tools against social Exclusion and Poverty Programme (STEP). Geneva, ILO.

Maki, O. 1993. "Gender and the labor market", in Journal of Japanese Studies. 19(1): 79-102.

Medel, J. R. and Riquelme, V. 1994. La salud ignorada: Temporeras de la fruticultura. Santiago, Centro de Estudios de la Mujer.

Mehra, R. and Gammage, S. 1999. "Trends, countertrends and gaps in women's employment", in World Development. 27(3): 533-550.

Miller, C. and Vivian, J. (eds.). 2002. Women's employment in the textile manufacturing sectors of Bangladesh and Morocco. Geneva, UNRISD.

Moghadam, V.M. 1999. "Gender and globalization: Female labor and women's mobilization", in Journal of World Systems Research. V(2): 367-388.

Murphy, M. 1995. "South African farm workers: Is trade union organization possible?", in South African Labour Bulletin. 19(3).

Nam, S. 1991. "Determinants of female labor force participation: A study of Seoul, South Korea, 19701980", in Sociological Forum. 6(4): 641-659. 
Nguyen, T.H. 2000. "The Asian economic crisis and employment problems for female garment and leather shoe workers in Hochiminh City", in Vietnam's Socio-economic Development. 21, Spring: 67-77.

Naples, N.A. and Desai, M. (eds.). 2002. Women's activism and globalization: Linking local struggles to transnational politics. London, Routledge.

Orbeta, A. C. 2002. Globalization and employment: The impact of trade on employment level and structure in the Philippines. Philippine Institute for Development Studies. Discussion Paper Series No. 2002-04.

Palley, M. L. 1990. "Women's status in South Korea: Tradition and change”, in Asian Survey. 30(12): 1136-1153.

Park, K.A. 1995. "Women workers in South Korea: The impact of export-led industrialization", in Asian Survey. 35(8), August: 730-756.

Raynolds, L.T. 2001. "New plantations, new workers: Gender and production politics in the Dominican Republic", in Gender and Society. 15(1): 7-28.

Reeves, M., Schafer, K., Hallward, K. and Katten, A. 1999. Fields of poison: California farmworkers and pesticides. San Francisco, Californians for Pesticide Reform.

Rios, P.N. 1990. "Export-oriented industrialization and the demand for female labor: Puerto Rican women in the manufacturing sector, 1952-1980", in Gender and Society. 4(3): 321-337.

Rowbotham, S. and Mitter, S. (eds.). 1994. Dignity and daily bread: New forms of economic organising among poor women in the Third World and the First. London, Routledge.

Safa, H.I. 1977. "The changing class composition of the female labor force in Latin America", in Latin American Perspectives. 4(4): 126-136.

Sen, G. 1999. Gendered labour markets and globalisation in Asia. UNCTAD/UNDP Occasional Paper No. 133.

Serna Calvo, M. del Mar. 1996. Legislation on women's employment in Latin America: A comparative study. Labour Law and Labour Relations Branch, Occasional Paper No. 11. Geneva, ILO.

SERNAM. 2001. Acuerdos de las comisiones de la agroexportacion para trabajadores y trabajadoras agricolas de temporada. Santiago, Servicio Nacional de la Mujer.

Singh, S. and Zammit, A. 2000. The global labour standards controversy: Critical issues for developing countries. France, South Perspectives.

Siok-Hwa, C. 1977. "Singapore women: Legal status, educational attainment and employment patterns", in Asian Survey. 17(4): 358-374.

Spooner, D. 2003. "International framework agreements: Implementing workers' rights in global corporations", in Federation News. 53(1). Institute of Employment Rights.

Standing, G. 1999a. "Global feminization through flexible labor: A theme revisited", in World Development. 27 (3): 583-602.

---- 1999b.Global labour flexibility: Seeking distributive justice. Basingstoke, Macmillan.

Thrupp, L., with Bergeron, C. and Waters, W.F. 1995. Bittersweet harvests for global supermarkets: Challenges in Latin America's agricultural export boom. Washington DC, World Resources Institute.

Tiano, S. 1994. Patriarchy on the line: Labor, gender, and ideology in the Mexican maquila industry. Philadelphia, Temple University Press.

United Nations. 1999. 1999 world survey on the role of women in development: Globalization, gender and work. New York. 
Venegas, S. 1993. "Programas de apoyo a temporeros y temporeras en Chile", in Gómez, S. and. Klein, E. (eds.), Los pobres del campo: El trabajador eventual. Santiago, FLACSO/PREALC, ILO.

----. 1992.Una gota al día, un chorro al año: El impacto social de la expansió frutícola. Santiago, GEA.

Wainerman, C. H., Sautu, R. and de Lattes, Z. R. 1980. "The participation of women in economic activity in Argentina, Bolivia and Paraguay: A comparative study", in Latin American Research Review. 15(2): 143-151.

Whitehead, A. 2001. Trade, trade liberalisation and rural poverty in low-income Africa: A gendered account. Background Paper for the UNCTAD 2001 Least Developed Countries Report. Brighton, University of Sussex.

WIEGO (various publications). Women in Informal Employment Globalizing and Organizing. See www.wiego.org

Wilkinson, B. 1994. Labour and industry in the Asia-Pacific: Lessons from industrialized countries. Berlin, de Gruyter.

Wilson, F. 1991. Sweaters: Gender, class and workshop-based industry in Mexico. Basingstoke, Macmillan. 



\section{Policy Integration Department Working Papers prepared for the World Commission on the Social Dimension of Globalization}

No. 16 International finance: Meeting the needs of people in developing countries, José Guilherme Almeida dos Reis

No. 17 The gender dimensions of the globalization of production, Stephanie Barrientos, Naila Kabeer and Naomi Hossain

No. 18 Social exclusion in the context of globalization, Jan Breman

No. 19 Gender and globalization: A macroeconomic perspective, Çağatay Nilüfer and Ertük Korkurt

No. 20 Globalization, social exclusion, and work: with special reference to informal employment and gender, Marilyn Carr and Martha Chen

No. 21 Resources for social development, Anthony Clunies Ross

No. 22 Does the new international trade regime leave room for industrialization policies in the middle-income countries?, Alisa DiCaprio and Alice Amsden

No. 23 Social dimension of globalization in Latin America: Lessons from Bolivia and Chile, Alvaro García Hurtado

No. 24 Globalization: Social impact and policy actions: A partly annotated bibliography, Bernhard Gunter and Rolph van der Hoeven

No. 25 The social dimension of global production systems, Susan Hayter

No. 26 Reforming global economic and social governance:

a critical review of recent programmatic thinking, Jeremy Heimans

No. 27 Corporate social responsibility: An issues paper, Michael Hopkins

No. 28 Upgrading in global value chains, John Humphrey

No. 29 Implications of globalization and economic restructuring for skills development in Sub-Sahara Africa, Richard K. Johanson

No. 30 The outcome and impact of the main international commissions on development issues, Frédéric Lapeyre

No. 31 Globalization and structural adjustment as a development tool, Frédéric Lapeyre

No. 32 Globalization and perceptions of social inequality, Malte Luebker

No. 33 The changing structure of trade linked to global production systems:

What are the policy implications?, William Milberg

No. 34 Corporate social responsibility: An overview of principles and practice, Jill Murray

No. 35 Inclusive development strategy in an era of globalization, Ignacy Sachs

No. 36 Social consequences of the globalization of the media and communications sector: Some strategic considerations, Seán Ó. Siochrú

No. 37 Globalization, history and international migration - A view from Latin America, Andrés Solimano

No. 38 Towards a different kind of globalization, or how the anti-globalizers view the world, Gijsbert van Liemt 